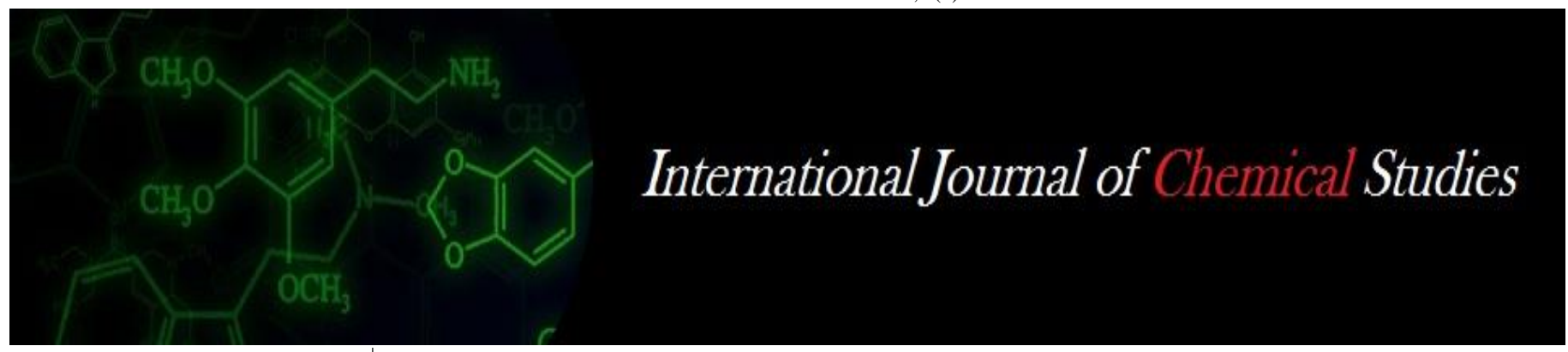

P-ISSN: 2349-8528

E-ISSN: 2321-4902

www.chemijournal.com

IJCS 2020; 8(4): 3240-3243

(C) 2020 IJCS

Received: 28-05-2020

Accepted: 29-06-2020

Nowsheen Nazir

Division of Fruit Science

SKUAST-K, Srinagar, Jammu and Kashmir, India

\section{MK Sharma}

Division of Fruit Science

SKUAST-K, Srinagar, Jammu

and Kashmir, India

\section{Aroosa Khalil}

Division of Fruit Science

SKUAST-K, Srinagar, Jammu

and Kashmir, India

Shemoo Nisar

Division of Fruit Science

SKUAST-K, Srinagar, Jammu and Kashmir, India

Kounser Javeed

Division of Fruit Science

SKUAST-K, Srinagar, Jammu

and Kashmir, India

Insha Majid

Division of Fruit Science

SKUAST-K, Srinagar, Jammu

and Kashmir, India

Corresponding Author:

Nowsheen Nazir

Division of Fruit Science

SKUAST-K, Srinagar, Jammu

and Kashmir, India

\section{Studies on exogenous application of plant growth regulators on storage changes in kiwifruit cv. Hayward}

\author{
Nowsheen Nazir, MK Sharma, Aroosa Khalil, Shemoo Nisar, Kounser \\ Javeed and Insha Majid
}

DOI: https://doi.org/10.22271/chemi.2020.v8.i4an.10154

\begin{abstract}
Effect of four different plant growth regulators viz., GA3 (25 and $50 \mathrm{mg} / \mathrm{litre})$, BA (10 and $20 \mathrm{mg} / \mathrm{litre}$ ), 2,4-D (10 and $25 \mathrm{mg} /$ litre), TRIA (10 and $20 \mathrm{mg} /$ litre) and a natural extract (4gm/litre) on storage changes in kiwifruit cv. Hayward were studied for two consecutive years. 11-year-old vines of kiwifruit cv. Hayward grown on a T-bar trellis system for two years were sprayed four weeks after full bloom. All the growth regulators proved effective in reducing physiological loss in weight. Application of 25 $\mathrm{mg} /$ litre GA3 sprayed four weeks after full bloom proved effective in maintaining higher firmness, TSS and vitamin $\mathrm{C}$ content after 20 days of ambient storage. Sensory evaluation reading after 20 days of ambient storage was also higher under this treatment. The study showed that the application of plant growth regulators viz., GA3 (25 and $50 \mathrm{mgL}-1)$, BA (10 and $20 \mathrm{mgL}-1), 2,4-\mathrm{D}$ (10 and $25 \mathrm{mgL}-1)$, TRIA (10 and $20 \mathrm{mgL}-1)$ and a natural extract (4gmL-1) four weeks after full bloom influences the storage changes after 20 days of ambient storage.
\end{abstract}

Keywords: Hayward, GA3, 2, 4-D, triacontanol, BA, storage changes

\section{Introduction}

Kiwifruit (Actinidia deliciosa Chev.) has emerged as a success story in temperate fruit growing areas in India. The fruit is very much acclaimed for its nutritive and medicinal value. It is rich is ascorbic acid, vitamin $\mathrm{E}$ and minerals like $\mathrm{K}, \mathrm{P}$ and $\mathrm{Ca}$. The important advantage of cultivation of this fruit is that it is available for marketing during October to December when other fruits are rarely available and therefore fetches good price. Among few cultivars of kiwifruit, Hayward is the most commercial due to its internal green colour and superior flavour. Firmness, TSS, and ascorbic acid content are the important quality characters of kiwifruit. Among various practices, application of plant growth regulators are the most important factor for quality kiwifruit production. Triacontanol (TRIA), a primary alcohol, is reported to cause increased uptake of water and nutrients and results in improved growth and CO2 exchange (Mishra and Srivastava, ${ }^{[8]}$. Gibberellic acid plays a major role in stimulating cell division and cell elongation (Xin et al., ${ }^{[15]}$. BA, a cytokinin play an important role in cell division whereas 2, 4-D an organic component is known to promote size in fruit crops. The effect of plant growth regulators depends upon climate, cultivar, stage and rate of application. So there was need to study the influence of these chemicals on storage changes in kiwifruit cv. Hayward under ambient conditions under temperate conditions of Kashmir valley.

\section{Materials and Methods}

The present investigation was carried out on 11 -year-old Hayward kiwifruit vines planted at a spacing of $6 \mathrm{~m} \times 5 \mathrm{~m}$. Canopies of the vines were trained on T-bar system. The vines were irrigated using drip irrigation system. All the vines were managed according to uniform agronomic practices. There were ten treatments viz. Gibberellic acid @50 mg/litre $\left(\mathrm{T}_{1}\right)$, Gibberellic acid @25 mg/litre ( $\left.\mathrm{T}_{2}\right)$, Benzylaminopurine (6-BA) @ $20 \mathrm{mg} / \mathrm{litre}\left(\mathrm{T}_{3}\right)$, Benzylaminopurine (6-BA) @ $10 \mathrm{mg} /$ litre $\left(\mathrm{T}_{4}\right), 2$, 4-Dicholorophenoxyacetic acid @ 25 mg/litre $\left(\mathrm{T}_{5}\right)$, 2, 4-Dicholorophenoxyacetic acid @10 mg/litre $\left(\mathrm{T}_{6}\right)$, Triacontanol (TRIA) @ 20 $\mathrm{mg} / \mathrm{litre}\left(\mathrm{T}_{7}\right)$, Triacontanol (TRIA) @ $10 \mathrm{mg} /$ litre $\left(\mathrm{T}_{8}\right)$, Natural extract (Auxin + Cytokinin + 
$\left.\mathrm{GA}_{3}\right)\left(\mathrm{T}_{9}\right)$ and control (water spray) $\left(\mathrm{T}_{10}\right)$. The treatments were applied foliarly 4-weeks after full bloom for two consecutive years. Treatments were replicated thrice with a plot size of 2 plants/treatment. For measuring physiological loss in weight, a total of 30 fruits with 10 fruits in each replication were kept separately in 3 boxes where each box represented a replication. The weight of the fruit after 20 days of storage under ambient conditions was recorded and per cent physiological loss in weight (PLW) was calculated by subtracting the final weight of fruit from initial weight as per the following equation:

PLW $(\%)=\frac{\text { Initial weight }- \text { Final weight }}{\text { Initial weight }} \times 100$

The pressure required to force an $8 \mathrm{~mm}$ plunger into the kiwifruit flesh was recorded as a measure of fruit firmness using 53205 digital fruit pressure tester (Toshiba-India). Observation were taken on diagonal sides of each fruit after peeling flesh of one square inch at harvest and after 20 days of storage under ambient conditions and results were expressed in Newton. Fruit TSS was measured with a hand refractometer (Tanco-0 to 50\% range) by placing few drops of juice from stem and stylar end of each fruit on the prism and taking the readings at harvest and after 20 days of storage under ambient conditions. The readings were corrected at $20^{\circ} \mathrm{C}$ with the help of temperature correction chart (Ranganna) ${ }^{[13]}$. Quantitative determination of ascorbic acid was done by 2, 6-dichlorophenol-indophenol visual titration method at harvest and after 20 days of storage under ambient conditions (Ranganna) ${ }^{[13]}$. Sensory evaluation was performed by using a 4 point scale (Ranganna) ${ }^{[13]}$. The fruits for organoleptic evaluation were presented to the panel of five judges in coded form and they were requested to note their sensory response on the basis of colour, taste, flavor, texture and overall acceptability on the basis of 4 point numerical scale as; very good: 4 , good: 3 , fair: 2 and poor: 1 . The data generated were subjected to statistical analysis as per the procedures described by Gomez and Gomez ${ }^{[4]}$.

\section{Results and Discussion}

The effect of plant growth regulators on physiological loss in weight and fruit firmness is given in Table 1. The results shown in Table 1 reveal that per cent weight loss of Hayward fruit during storage was significantly influenced by different growth hormones during both the years of study. There was a gradual increase in per cent physiological loss in weight of Hayward fruits during storage period of 20 days irrespective of treatments.

All the treatments had great influence in reducing the physiological loss in weight during storage as compared to control. Physiological loss in weight was significantly lowest with the application of $\left(\mathrm{T}_{2}\right) 25 \mathrm{mg} / \mathrm{litre} \mathrm{GA}_{3}$ (3.13 and $3.17 \%$ ) followed by ( $\left.\mathrm{T}_{1}\right) 50 \mathrm{mg} /$ litre $\mathrm{GA}_{3}\left(3.34\right.$ and $3.49 \%$ ) and $\left(\mathrm{T}_{6}\right)$ $10 \mathrm{mg} / \mathrm{litre} 2$, 4-D (3.41 and $3.99 \%)$ than all other treatments. The control recorded significantly higher physiological loss in weight (5.24 and 6.02\%) during both the years. Physiological loss in weight of fruit is mainly due to evaporation, respiration and degradation process occurring during postharvest handling of fruits (Haard and Salunkhe, ${ }^{[6]}$. It has been suggested that $\mathrm{GA}_{3}$ influences cuticle thickness and dimensions of the epidermal cells (Mohamed et al.,) ${ }^{[9]}$. The results are inconformity with the findings of Marzouk and Kassem $^{[7]}$.
At harvest, fruit firmness was highest $(7.76$ and $7.55 \mathrm{~N})$ in fruits treated with $\left(\mathrm{T}_{2}\right) 25 \mathrm{mg} /$ litre $\mathrm{GA}_{3}$ and lowest under control (water spray). Fruits lost its firmness with the advancement of ripening period during ambient storage although treated fruits were firmer than the untreated ones in both the years. Highest fruit firmness after 20 days of ambient storage was recorded in fruits treated with $\left(\mathrm{T}_{2}\right) 25 \mathrm{mg} / \mathrm{litre}$ $\mathrm{GA}_{3}(5.85$ and $6.54 \mathrm{~N})$ followed by $\left(\mathrm{T}_{5}\right) 25 \mathrm{mg} /$ litre 2 , 4-D $(5.73$ and $6.42 \mathrm{~N})$. The lowest fruit firmness after 20 days of ambient storage was obtained in untreated fruits (4.98 and $5.79 \mathrm{~N}$ ) in both seasons, respectively. Spraying with $\mathrm{GA}_{3}$ significantly increased the average fruit firmness. Decreased loss of fruit firmness with $\mathrm{GA}_{3}$, application was also observed by Okan et al. ${ }^{[12]}$.

At harvest, total soluble solids were highest (12.91 and 13.32 ${ }^{\circ}$ Brix) in fruits treated with $\left(\mathrm{T}_{2}\right) 25 \mathrm{mg} /$ litre $\mathrm{GA}_{3}$ during both the years of study. With the advancement of storage period, there was increase in the total soluble solids of fruits (Table 2). During first year maximum total soluble solids after 20 days of ambient storage was recorded in fruits treated with $\left(\mathrm{T}_{2}\right) 25 \mathrm{mg} /$ litre $\mathrm{GA}_{3}\left(14.32{ }^{\circ} \mathrm{Brix}\right)$ which was statistically at par with $\left(\mathrm{T}_{1}\right) 50 \mathrm{mg} /$ litre $\mathrm{GA}_{3}\left(14.01{ }^{0} \mathrm{brix}\right)$. Lowest total soluble solids $\left(11.26{ }^{\circ} \mathrm{Brix}\right)$ after 20 days of ambient storage were recorded in control. During second year $\left(\mathrm{T}_{2}\right) 25 \mathrm{mg} / \mathrm{litre}$ $\mathrm{GA}_{3}$ recorded highest total soluble solids (14.91 $\left.{ }^{\circ} \mathrm{Brix}\right)$ after 20 days of ambient storage. Treatment $\left(\mathrm{T}_{1}\right) 50 \mathrm{mg} / \mathrm{litre} \mathrm{GA}_{3}$ $\left(14.78{ }^{\circ}\right.$ Brix) and $\left(\mathrm{T}_{6}\right) 10 \mathrm{mg} /$ litre 2,4-D (14.66 $\left.{ }^{\circ} \mathrm{Brix}\right)$ were statistically at par with $\left(\mathrm{T}_{2}\right) 25 \mathrm{mg} / \mathrm{litre} \mathrm{GA}_{3}\left(14.91^{\circ} \mathrm{Brix}\right)$. The increase in TSS after storage may be attributed partly to the conversion of organic acids to sugars through gluconeogenesis (Echeverria and Ismail,) ${ }^{[2]}$. Moreover, the degradation of cellulose, hemicellulose and pectin from cell walls within fruit segments might release soluble components which could have a direct effect on TSS (Echeverria et al.,) ${ }^{[3]}$. These results coincide with the findings of Singh et al. ${ }^{[14]}$. Fruit vitamin $\mathrm{C}$ content at harvest was higher (92.75 and $92.76 \mathrm{mg} / 100 \mathrm{~g})$ with $\left(\mathrm{T}_{2}\right) 25 \mathrm{mg} /$ litre $\mathrm{GA}_{3}$ during both the years of study. However maximum vitamin $\mathrm{C}$ content after 20 days of ambient storage was observed in $\left(\mathrm{T}_{2}\right) 25 \mathrm{mg} / \mathrm{litre} \mathrm{GA}_{3}$ $\left(83.59\right.$ and $84.63 \mathrm{mg} / 100 \mathrm{~g}$ ) followed by $\left(\mathrm{T}_{1}\right) 50 \mathrm{mg} / \mathrm{litre} \mathrm{GA}_{3}$ (80.98 and $83.64 \mathrm{mg} / 100 \mathrm{~g})$ and $\left(\mathrm{T}_{6}\right) 10 \mathrm{mg} /$ litre 2,4-D (82.36 and $83.77 \mathrm{mg} / 100 \mathrm{~g}$ ), respectively during both the years of study (Table 2). The lowest vitamin $\mathrm{C}$ content after 20 days of ambient storage was recorded in control (65.84 and 69.79 $\mathrm{mg} / 100 \mathrm{~g}$ ) during both the years. As regards the Hayward fruits, its ascorbic acid content and its retention during storage period is of commercial importance. The continuous decrease in ascorbic acid content with the advancement of storage period was observed in all the treatments and this decrease was significantly more in untreated fruits than the treated fruits. However maximum decrease in vitamin $\mathrm{C}$ content was observed in control and minimum in $\mathrm{GA}_{3}$ treated fruits. This pattern of retention of ascorbic acid, might be due to the lowering of respiration or oxidation of ascorbic acid in the treated fruits. These results are in conformity with the findings of Gupta and Mukherjee ${ }^{[5]}$ and Nath et al. ${ }^{[11]}$.

Significant differences among different treatments on organoleptic qualities of fruits after 20 days of ambient storage were recorded during both the years of study (Table 3 ). The maximum score was recorded with the application of $\left(\mathrm{T}_{2}\right) 25 \mathrm{mg} / \mathrm{litreGA}_{3}$ (3.25 and 3.27) followed by $\left(\mathrm{T}_{1}\right) 50$ $\mathrm{mg} /$ litre $\mathrm{GA}_{3}$ (3.24 and 3.26), respectively during both the years. The least score was observed in untreated fruits $(2.02$ and 2.11). Positive relationships between biochemical analysis data and taste panel results, including a correlation 
between the sweetness of fruits and their TSS have been identified by many researchers (Azodanlou et al., ) ${ }^{[1]}$. In the present study the panellists graded $25 \mathrm{mg} /$ litre $\mathrm{GA}_{3}$ treated fruits as having the best taste, aroma, and highest sweetness and were also classified among those having the lowest acidity and best flavor followed by fruits from the $50 \mathrm{mg} /$ litre $\mathrm{GA}_{3}$ and $10 \mathrm{mg} / \mathrm{litre} \mathrm{BA}$. The control fruit had low values for taste, appearance, and sweetness. It has been suggested that plant growth regulator treated fruits accumulate the high percentage of sugar, polyphenolic compound and antioxidant substances in fruits, thus increase its taste, flavour as well as quality (Moneruzzaman et al., $)^{[10]}$.

From the above discussion it may be concluded that application of plant growth regulators 4-weeks after full bloom improved storage parameters after 20 days of ambient storage. Among different treatments, application of 25 $\mathrm{mg} /$ litre $\mathrm{GA}_{3}$ proved more effective in maintaining higher firmness, TSS and vitamin C content after 20 days of ambient storage. Sensory evaluation reading after 20 days of ambient storage was also higher under this treatment.

Table 1: Effect of exogenous application of plant growth regulators on physiological loss in weight (\%) and fruit firmness (N) in kiwifruit cv. Hayward under ambient storage after 20 days

\begin{tabular}{|c|c|c|c|c|c|c|}
\hline \multirow{2}{*}{ Treatments } & \multirow{2}{*}{ Physiological loss in weight $(\%)$} & \multicolumn{5}{|c|}{ Firmness $(\mathbf{N})$} \\
\cline { 2 - 7 } & & \multicolumn{3}{|c|}{$\mathbf{1}^{\text {st }}$ year } & \multicolumn{2}{c|}{$\mathbf{2}^{\text {nd }}$ year } \\
\cline { 2 - 7 } & $\mathbf{1}^{\text {st }}$ year & $\mathbf{2}^{\text {nd }}$ year & At harvest & After 20 days of storage & At harvest & After 20 days of storage \\
\hline $\mathrm{T}_{1}$ & 3.34 & 3.49 & 7.69 & 5.62 & 7.50 & 6.32 \\
\hline $\mathrm{T}_{2}$ & 3.13 & 3.17 & 7.76 & 5.85 & 7.55 & 6.54 \\
\hline $\mathrm{T}_{3}$ & 3.50 & 4.25 & 7.34 & 5.53 & 7.13 & 6.22 \\
\hline $\mathrm{T}_{4}$ & 3.48 & 4.21 & 7.46 & 5.55 & 7.25 & 6.24 \\
\hline $\mathrm{T}_{5}$ & 3.45 & 4.02 & 7.64 & 5.73 & 7.46 & 6.42 \\
\hline $\mathrm{T}_{6}$ & 3.41 & 3.99 & 7.53 & 5.62 & 7.32 & 6.31 \\
\hline $\mathrm{T}_{7}$ & 3.52 & 4.56 & 7.32 & 5.60 & 7.37 & 6.45 \\
\hline $\mathrm{T}_{8}$ & 3.50 & 4.49 & 7.05 & 5.58 & 7.07 & 6.36 \\
\hline $\mathrm{T}_{9}$ & 3.51 & 4.52 & 7.23 & 5.41 & 7.29 & 6.28 \\
\hline $\mathrm{T}_{10}$ & 5.24 & 6.02 & 7.01 & 4.98 & 7.04 & 5.79 \\
\hline $\mathrm{CD}_{(0.05)}$ & 0.17 & 0.29 & 0.08 & 0.15 & 0.04 & 0.19 \\
\hline
\end{tabular}

Table 2: Effect of exogenous application of plant growth regulators on total soluble solids and vitamin C content in kiwifruit cv. Hay ward under ambient storage after 20 days

\begin{tabular}{|c|c|c|c|c|c|c|c|c|}
\hline \multirow{3}{*}{ Treatments } & \multicolumn{4}{|c|}{ T.S.S. $\left({ }^{\circ}\right.$ Brix $)$} & \multicolumn{4}{|c|}{ Vitamin C (mg/100g) } \\
\hline & \multicolumn{2}{|r|}{ 1 $^{\text {st }}$ year } & \multicolumn{2}{|r|}{$2^{\text {nd }}$ year } & \multicolumn{2}{|r|}{$1^{\text {st }}$ year } & \multicolumn{2}{|c|}{$2^{\text {nd }}$ year } \\
\hline & $\begin{array}{c}\text { At } \\
\text { harvest }\end{array}$ & $\begin{array}{c}\text { After } 20 \text { days of } \\
\text { storage }\end{array}$ & $\begin{array}{c}\text { At } \\
\text { harvest }\end{array}$ & $\begin{array}{c}\text { After } 20 \text { days of } \\
\text { storage }\end{array}$ & $\begin{array}{c}\text { At } \\
\text { harvest }\end{array}$ & $\begin{array}{c}\text { After } 20 \text { days of } \\
\text { storage }\end{array}$ & $\begin{array}{c}\text { At } \\
\text { harvest }\end{array}$ & $\begin{array}{c}\text { After } 20 \text { days of } \\
\text { storage }\end{array}$ \\
\hline $\mathrm{T}_{1}$ & 12.80 & 14.01 & 13.11 & 14.78 & 90.14 & 80.98 & 91.79 & 83.64 \\
\hline $\mathrm{T}_{2}$ & 12.91 & 14.32 & 13.32 & 14.91 & 92.75 & 83.59 & 92.76 & 84.63 \\
\hline $\mathrm{T}_{3}$ & 12.29 & 12.62 & 12.45 & 13.35 & 84.16 & 75.01 & 86.66 & 74.29 \\
\hline $\mathrm{T}_{4}$ & 12.42 & 12.78 & 12.84 & 13.49 & 85.97 & 82.35 & 88.91 & 83.76 \\
\hline $\mathrm{T}_{5}$ & 12.65 & 13.21 & 12.98 & 13.42 & 89.43 & 79.08 & 90.48 & 82.20 \\
\hline $\mathrm{T}_{6}$ & 12.78 & 13.34 & 13.23 & 14.66 & 86.67 & 82.36 & 89.11 & 83.77 \\
\hline $\mathrm{T}_{7}$ & 12.11 & 12.32 & 12.65 & 13.27 & 82.36 & 74.95 & 83.17 & 72.96 \\
\hline $\mathrm{T}_{8}$ & 11.93 & 12.45 & 12.87 & 12.91 & 80.26 & 75.00 & 84.28 & 74.97 \\
\hline $\mathrm{T}_{9}$ & 11.10 & 12.21 & 12.11 & 13.19 & 86.29 & 77.12 & 85.39 & 74.32 \\
\hline $\mathrm{T}_{10}$ & 11.25 & 11.26 & 11.32 & 11.76 & 79.12 & 65.84 & 81.14 & 69.79 \\
\hline $\mathrm{CD}_{(0.05)}$ & 0.51 & 0.95 & 0.07 & 0.76 & 1.09 & 0.03 & 1.11 & 0.04 \\
\hline
\end{tabular}

Table 3: Effect of exogenous application of plant growth regulators on sensory evaluation of kiwifruit cv. Hayward under ambient storage after 20 days

\begin{tabular}{|c|c|c|}
\hline Treatments & $\mathbf{1}^{\text {st }}$ year & $\mathbf{2}^{\text {nd }}$ year \\
\hline $\mathrm{T}_{1}$ & 3.24 & 3.26 \\
\hline $\mathrm{T}_{2}$ & 3.25 & 3.27 \\
\hline $\mathrm{T}_{3}$ & 3.17 & 3.18 \\
\hline $\mathrm{T}_{4}$ & 3.19 & 3.20 \\
\hline $\mathrm{T}_{5}$ & 2.96 & 2.84 \\
\hline $\mathrm{T}_{6}$ & 3.02 & 2.99 \\
\hline $\mathrm{T}_{7}$ & 3.01 & 3.00 \\
\hline $\mathrm{T}_{8}$ & 2.98 & 3.02 \\
\hline $\mathrm{T}_{9}$ & 2.97 & 2.98 \\
\hline $\mathrm{T}_{10}$ & 2.02 & 2.11 \\
\hline $\mathrm{CD}_{(0.05)}$ & 0.89 & 0.95 \\
\hline
\end{tabular}

\section{References}

1. Azodanlou R, Darbellay C, Luisier JL, Villettaz JC, Amado R. Quality assessment of strawberries (Fragaria species). J Agri Food Che. 2003; 51:715-721.
2. Echeverria E, Ismail M. Changes in sugars and acids of citrus fruits during storage. Pro. Florida S Hort. Soc. 1987; 100:50-52.

3. Echeverria E, Jacoqueline KB, Wicker L. Effect of cell wall hydrolysis on Brix in citrus fruits. Pro Florida $\mathrm{S}$ Hort. Soc. 1988; 101:150-154.

4. Gomez KA, Gomez AA. Statistical procedures for agricultural research. John Wiley and Sons. Inc., New York, 1983.

5. Gupta VK, Mukherjee D. The influence of wax emulsion, morphactin and gibberellic acid on the storage behaviour of Indian gooseberry fruits. Sci Hort. 1982; 16:155-162.

6. Haard NF, Salunkhe DK. Symposium on post-harvest biology and handling of fruits and vegetables. The AVI Publishing Co. Inc, 1975.

7. Marzouk HA, Kassem HA. Improving yield, quality, and shelf life of Thompson Seedless grapevine by preharvest foliar applications. Sci. Hort. 2011; 130:425-430.

8. Mishra A, Srivastava A. Effect of triacontanol formulation Miraculan on photosynthesis, growth, 
nutrient uptake, and essential oil yield of lemon grass (Cymbopogan flexuous) Stevol, Watts ((Steva) Wats.). Pl. Growth Reg. 1991; 10:57-63.

9. Mohamed MAA, Aisha SAG, Abd El-Ghany AA. Influence of seaweed extract (Acadian), EDTA calcium, ascorbic acid and gibberellic acid pre harvest application on Crimson seedless table grape: II-storability. Egyptian J Agri Res. 2007; 85:2257-2277.

10. Moneruzzaman KM, Hossain ABMS, Normaniza O, Boyce AN. Growth, yield and quality responses to GA3 of wax apple Syzygium samarangense. African J Biotech. 2011; 10:11911-11918.

11. Nath V, Singh IS, Sanjeev K, Pandey AK, Kumar S. Effect of postharvest treatment on shelf-life of aonla fruits. Prog Hort. 1992; 24:79-82.

12. Okan O, Omur D, Ali K. Effect of preharvest gibberellic acid treatments on postharvest quality of sweet cherry. $\mathrm{J}$ Food, Agri Env. 2006; 4:189-191.

13. Ranganna S. Hand Book of Analysis and Quality Control for Fruit and Vegetable Products. Tata Mc Graw Hill Publishing Co. Ltd., New Delhi, India, 1986, 1-30.

14. Singh AK, Bhartiya SP, Bhutani VP. Effect of foliar spray of plant bio regulators and boric acid on nutrient status of apple fruits. Haryana J Hort Sci. 2000; 29:166168.

15. Xin PG, Xiang SX, Che PG, Xin SX, Chen XL. A study on distribution of PP333 in young apple trees and its growth inhibition effect and inhibition relieving with GA3. J Shandong Agri Uni. 1994; 25:1-8 